\title{
A NEW PERSPECTIVE ON THE UNIVERSALITY DEBATE: REVERSE MODERATE RELATIVISM IN THE ISLAMIC CONTEXT
}

\author{
Jason Morgan-Foster
}

I. INTRODUCTION $\ldots \ldots \ldots \ldots \ldots \ldots \ldots \ldots \ldots \ldots \ldots \ldots \ldots$

II. THE UNIVERSALITY/CULTURAL RELATIVIST QUESTION IN ISLAM . . 37

III. THREE THEORIES EXAMINED $\ldots \ldots \ldots \ldots \ldots \ldots \ldots \ldots \ldots . \ldots \ldots$

A. Universalism ....................... 40

1. Philosophical Universalism $\ldots \ldots \ldots \ldots \ldots \ldots \ldots \ldots, 41$

2. Positivist Universalism . . . . . . . . . . . . . . 41

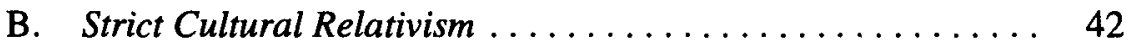

C. Moderate Cultural Relativism ................ 43

IV. ReVerse Moderate Relativism: A Different PersPeCtive ON THE DEBATE $\ldots \ldots \ldots \ldots \ldots \ldots \ldots \ldots \ldots \ldots \ldots \ldots \ldots$

A. Introduction: False Universalism and the Flaw of Perspective ........................... 46

B. Support for Reverse Moderate Relativism in Islamic Law . . . 48

1. Islam's Zakat and the International Right to Social Security ........................ 49

2. The Synergistic Relationship between the 'Umma and the individual in Islam .......... 54

3. The Co-existence of Duties and Rights in Islam ...... . 58

4. Islamic Gradualism and Dynamic Human Rights Norms . 63

C. The Superiority of Reverse Moderate Relativism ......... . 66

V. Conclusion ............................. 66

\section{INTRODUCTION}

The goal of the human rights movement to formulate a jurisprudence of rights valid for all of humanity is considered laudable by some,' offensive to

* Jason Morgan-Foster is a JD candidate at the University of Michigan Law School and a graduate student in Middle Eastern Studies at the University of Michigan. In Summer 2001, he was an intern for the Human Rights Committee and the Committee on the Elimination of Racial Discrimination at the United Nations Office of the High Commissioner for Human Rights, Geneva. He would like to thank Professor Marcia Inhorn and Professor Sherman Jackson for their guidance and review of earlier drafts.

1. HENRY J. STEINER \& PHILIP ALSTON, INTERNATIONAL HUMAN RightS In CONTEXT 366 (2d ed. 2000) ("[T] he partisans of universality claim that international human rights . . . are and must be the same everywhere."). 
others. $^{2}$ The universality/cultural relativist debate on human rights has developed around the question of just how realistic it is to form universal rights in the presence of vastly differing local cultures. ${ }^{3}$ The compatibility (or noncompatibility) of Islam with human rights provides a particularly rich, and controversial, window into this debate. In Part II, I will briefly summarize the main areas in which human rights commentators have portrayed a tension between Islamic Law (hereinafter either "Islamic Law" or "Shari'a") and human rights norms. In Part III, I will explore the three most common theories which have been propagated on the question of the universality of human rights-universalism, strict cultural relativism, and moderate cultural relativism -concluding that none of these offers a satisfactory analysis of the issue. In Part IV, the main part of this note, I begin by noting that, just as the American Critical Legal Studies (CLS) movement in the 1970s criticized the tacit acceptance of the oppressor view as neutral, the same critique could be made of the existing theories on the universality of human rights. I propose a new theory, reverse moderate relativism, which offers a superior way to conceptualize the universality question by focusing on local (in this case, Islamic) norms instead of maintaining an international bias. I will test this theory in four areas of Islamic law: the use of Zakat (almsgiving), the relationship between 'umma (the Islamic community) and the individual, the coexistence of duties and rights in Islam, and the concept of Islamic gradualism. In these four areas, international human rights norms and local norms are converging, but contrary to the premise of moderate cultural relativists like Abdullahi $\mathrm{Al} \mathrm{An-Na'im,} \mathrm{they} \mathrm{are}$ not (and should not be) converging towards international norms in all cases. Rather, in these four areas, international human rights norms and Islamic norms are converging towards a more Islamic standard. In Part V, I conclude that while strict cultural relativism/universality are both unrealistic, and moderate cultural relativism is neo-colonialist, reverse moderate relativism offers a refreshing now focus which continues to search for common ground between international and local norms, but with a necessary attention to underlying power dynamics.

2. Id. at 367 ("To the relativist, these [human rights] instruments and their pretension to universality may suggest primarily the arrogance or 'cultural imperialism' of the West, given the West's traditional urge . . . to view its own forms and beliefs as universal, and to attempt to universalize them.").

3. In this note, I will use the terms "local cultures" and "local norms" to refer to any culture/norm which is not an international one. But, I employ these terms broadly, to mean anything from a truly "local" culture/norm (such as the culture/norm of a specific and localized indigenous group), to domestic cultures/norms (such as the culture/norms of a specific country), to a regional or even international religious culture/norm (such as Islam/Islamic law). Thus, I refer to Islamic law as a "local norm" solely to distinguish it from international norms, since the term "domestic norms" would not be appropriate in light of the wide popularity of Islam throughout the world. 


\section{ThE UNIVERSALITY/CULTURAL RELATIVIST QUESTION IN ISLAM}

Unquestionably, there are many areas of potential tension between Shari'a and international human rights norms. In this section, I outline the areas that (Western) human rights commentators most commonly raise when the compatibility of Shari'a and human rights is at issue. The largest and mostoften discussed point of contention involves the status of women, ${ }^{4}$ who generally cannot hold a political or judicial office, ${ }^{5}$ sometimes lack capacity to initiate a marriage contract or obtain a unilateral divorce, ${ }^{6}$ and may inherit half as much as an equally situated male. ${ }^{7}$ A woman's testimony in court is valued at half that of a man's, ${ }^{8}$ and monetary compensation for violent crimes (diya) is less for female victims than for male. ${ }^{9}$ According to some interpretations of Shari' $a$ (some of which are state-sanctioned), her husband may chastise her, including "light beating," 10 demand intercourse at any time, and restrict her freedom of movement. ${ }^{11}$ The presence of polygamy is also considered a

4. See, e.g., Donna E. Arzt, The Application of International Human Rights Law in Islamic States, 12 Hum. RTs. Q. 202, 208 (1990) (describing the issue of sexual equality as "[p]robably the most celebrated inequality under traditional Islamic law"); Abdullahi Ahmed An-Na'im, Human Rights in the Muslim World: Socio-Political Conditions and Scriptural Imperatives, A Preliminary Inquiry, 3 HARV. HUM. RTS. J. 13, 3646 (1990) (noting that "[t]he most important general principle of Shari' a influencing the status and rights of women is the notion of qawama (citing Holy Qur'an 4:34 ("Men have qawama [guardianship and authority] over women because of the advantage they [men] have over them [women]."))); Rebecca J. Cook, Reservations to the Convention on the Elimination of All Forms of Discrimination Against Women, $30 \mathrm{VA}$. J. INT'L L. 643 (1990); Leila P. Sayeh \& Adriaen M. Morse, Jr., Islam and the Treatment of Women: An Incomplete Understanding of Gradualism. 30 TEX. INT'L L.J. 311 (1995); Bharathi Anandhi Venkatraman, Islamic States and the United Nations Convention on the Elimination of All Forms of Discrimination Against Women: Are the Shari' $a$ and the Convention Compatible? 44 AM. U. L. REv. 1949 (1995); ANN ELIZABETH MAYER, ISLAM AND HUMAN RIGHTS: TRADITION AND POLITICS 97-130 (3d ed.1999).

5. An-Na'im, supra note 4, at 37 ("[The] notion of general and specific qawama has had far reaching consequences for the status and rights of women in both the private and public domains. For example, Shari'a provides that women are disqualified from holding general public office, which involves the exercise of authority over men, because, in keeping with the verse 4:34 of the Qur'an, men are entitled to exercise authority over women and not the reverse").

6. Arzt, supra note 4, at 223 (noting that "Iran, Pakistan, and Tunisia allow wives to seek divorce in a greater number of instances than Shari'a traditionally allowed ... Divorce reforms have also been instituted in Algeria, Somalia, and the People's Democratic Republic of Yemen.").

7. Id. at 208; but see id. at 223 ("Tunisia has ... altered inheritance law to allow daughters a greater share.").

8. Holy Qur'an 2:282; Arzt, supra note 4, at 208; An-Na'im, supra note 4, at 39.

9. An-Na'im, supra note 4, at 39.

10. Arzt, supra note 4, at 208.

11. See, e.g. Third Periodic Reports of States Parties Due In 1998: Yemen. 18/10/2001. U.N. Human Rights Committee, I 141, U.N. Doc. CCPR/C/YEM/2001/3 (2001) (citing The Yemen Personal Status Act No. 20 of 1992, as amended, article 40, available at http:/www.unhchr.ch/tbs/doc.nsf/(Symbol)/ CCPR. C.YEM.2001.3.EnOpendocument (last visited Oct. 3, 2003). 
problem by Western human rights commentators. ${ }^{12}$ A close second in terms of shear amount of commentary after the status of women is the frequently-debated tension between human rights and Shari' $a$ in the area of religious freedom, ${ }^{13}$ including religious discrimination ${ }^{14}$ and Shari' a law of apostasy. ${ }^{15} \mathrm{~A}$ third and less-discussed area of tension is criminal defense rights, particularly the use of criminal penalties as retaliation (qisas). ${ }^{16}$ Fourth, a potential tension exists

\begin{abstract}
A husband has a right to his wife's obedience in matters affecting the family's interests, particularly with regard to the following: She must ... permit him to live with her and enjoy access to her ... permit him to have licit intercourse with her ... obey his orders without obstinacy and perform her work in the conjugal home ... not leave the conjugal home without his permission
\end{abstract}

Id.

12. An-Na'im, supra note 4, at 38-39; Arzt, supra note 4, at 222-23 (noting that Tunisia has abolished polygamy, and that Syria, Morocco, and Pakistan have restricted it).

13. See, e.g., Arzt, supra note 4, at 208-09; MAYER, supra note 4, at 131-74.

14. Compare Holy Qur'an 9:5 ("Slay them [those who do not believe in revealed scriptures] wherever you may find them."), and id. at 3:85 ("If anyone desires a religion other than Islam, never will it be accepted of him; and in the hereafter he will be among the losers."), with Universal Declaration of Human Rights, art. XVII, G.A. Res. 217A, U.N. GAOR, 3d Sess., at 5, U.N. Doc. A/810 (1948), http://www.unhchr .ch/udhr/lang/eng.pdf (last visited Oct. 10, 2003) [hereinafter $U D H R$ ] ("Everyone has the right to freedom of thought, conscience and religion . . . ."); id. at art. II, at 2, ("Everyone is entitled to all the rights and freedoms set forth in this Declaration, without distinction of any kind, such as . . religion . ..."); International Covenant on Civil and Political Rights, Dec. 19, 1966, art. XVIII, para. 1, 999 U.N.T.S. 171, 178 (entered into force Mar. 23, 1976) [hereinafter ICCPR] ("Everyone shall have the right to freedom of thought, conscience and religion."); id. at art. II, para. 1, at 173 ("Each State Party to the present Covenant undertakes to respect and to ensure to all individuals within its territory and subject to its jurisdiction the rights recognized in the present Covenant, without distinction of any kind, such as . . religion . . .."). See also Arzt, supra note 4, at 223 (reporting that "the principles of religious freedom and nondiscrimination against religious minorities are now constitutionally protected in the majority of Islamic states," but noting that "some such provisions are in conflict with other constitutional sections that establish Islam as the official state religion or Shari' $a$ as a principle source of legislation").

15. Compare An-Na'im, supra note 4, at 23 ("According to Shari'a, a Muslim who repudiates his faith in Islam, whether directly or indirectly, is guilty of a capital offense punishable by death."), with UDHR, supra note 14, at art. XVIII, at 5 ("Everyone has the right to freedom of thought, conscience and religion; this right includes freedom to change his religion or belief') (emphasis added), and ICCPR supra note 14, at art. XVIII, paras. 1-2, at 178 ("Everyone shall have the right to freedom of thought, conscience and religion. This right shall include freedom to have or to adopt a religion or belief of his choice, and ... [n]o one shall be subject to coercion which would impair his freedom to have or to adopt a religion or belief of his choice."); but see Holy Qur' an 2:256 ("There should be no compulsion in religion . . ."); see An-Na'im, supra note 4, at $48 \mathrm{nn} .150-51$.

16. Compare Arzt, supra note 4, at 208 ("Islamic law provides for penalties not to promote rehabilitation of the criminal but as a retaliation (qisas), either by financial extraction or bodily mutilation."), with $U D H R$, supra note 14, art. V, at 2 ("No one shall be subjected to torture or to cruel, inhuman or degrading treatment or punishment."), and ICCPR, supra note 14, at art. VII, at 175 ("No one shall be subjected to torture or to cruel, inhuman or degrading treatment or punishment."). 
between Shari' $a$ and a number of Civil and Political rights, such as the right to be free from slavery, ${ }^{17}$ freedom of expression, ${ }^{18}$ and non-discrimination. ${ }^{19}$

Faced with all of these possible tensions, one is likely to conclude that Islamic law and human rights are prima facie incompatible. But, a fertile debate continues to rage over the extent to which this is true. In the next section, I will summarize the three main theories dominating this debate - universalism, strict cultural relativism, and moderate cultural relativism - and conclude that none of these theories is adequate.

\section{THREe TheOrIES EXAMINED}

In her comprehensive article on cultural relativism, Islam, and human rights, ${ }^{20}$ Kimberly Younce Schooley provided a useful framework with which to describe and analyze the universality debate, by identifying five distinct camps in the discourse: strict cultural relativism, ${ }^{21}$ moderate cultural relativism, ${ }^{22}$

17. Compare An-Na'im, supra note 4, at 22 (“Although slavery was formally abolished in all Muslim countries through secular law, the institution itself remains lawful under Shari'a to the present day"), with $U D H R$, supra note 14, at art. IV, at 2 ("No one shall be held in slavery or servitude; slavery and the slave trade shall be prohibited in all their forms."), and ICCPR, supra note, at art. VIII, paras. 1-2, at 175 ("No one shall be held in slavery; slavery and the slave-trade in all their forms shall be prohibited . . . No one shall be held in servitude").

18. Compare An-Na'im, supra note 4, at 23 ("The Shari'a law of apostasy can be used to restrict other human rights such as freedom of expression."), with UDHR, supra note 14, at art. XIX, at 5 ("Everyone has the right to freedom of opinion and expression ...."); ICCPR, supra note 14, at art. XIX, para. 2 , at 178 ("Everyone shall have the right to freedom of expression ...").

19. See An-Na'im, supra note 4, at 24-25 (describing a three-tiered rights entitlement based on religious adherence under Shari'a, including Muslims; $A$ hl al-Kitab, believers in a divinely revealed scripture such as Christians and Jews; and non-believers. Muslims are full citizens enjoying all Shari'a rights and freedoms. Ahl al-Kitab hold the status of dhimma, a compact with the Muslim state guaranteeing them inferior rights and freedoms to Muslims, including lack of equality with Muslims, a lower diya (financial compensation for murder or bodily harm) than Muslims, non-application of the Muslim hadd of qadhf ("criminal penalty for the unproven accusation of fornication"), inability of a dhimmi man to marry a Muslim woman, and subjection to a jizya poll tax. The rights of unbelievers are limited even further, with recognition as dhimmis as a best-case scenario); but cf. $U D H R$, supra note 14, at art. II, at 2 ("Everyone is entitled to all the rights and freedoms set forth in this Declaration, without distinction of any kind, such as ... religion ...."), and ICCPR, supra note 14, at art. II, para. 1, at 173 ("Each State Party to the present Covenant undertakes to respect and to ensure to all individuals within its territory and subject to its jurisdiction the rights recognized in the present Covenant, without distinction of any kind, such as . . religion . . ..").

20. Kimberly Younce Schooley, Cultural Sovereignty, Islam, and Human Rights-Toward a Communitarian Revision, 25 CUMB. L. REV. 651, 678-79 (1994).

21. Strict cultural relativists believe that any contemplation of international human rights is a priori offensive to local cultures. See Schooley, supra note 20, at 679-82.

22. Moderate cultural relativists believe that attention to local cultures precludes the universality of certain human rights, but that a certain set of "core" rights do transcend national and cultural boundaries; the moderate cultural relativist thus concentrates on separating the minimal core rights from the culturally 
universalism, ${ }^{23}$ feminism, ${ }^{24}$ and communitarianism. ${ }^{25}$ Particularly useful is her distinction between strict cultural relativism, in which any contemplation of international human rights is a priori offensive to local cultures, ${ }^{26}$ and moderate cultural relativism, in which attention to local cultures precludes the universality of certain human rights, but that a certain set of "core" rights do transcend national and cultural boundaries. ${ }^{27}$ In this section, I will explore the three dominant categories Schooley identifies: Universalism, strict cultural relativism, and moderate cultural relativism. ${ }^{28}$ I will conclude that, for various reasons, each of these theories on the interplay between international and local norms is unsatisfactory.

\section{A. Universalism}

There are many human rights commentators that want human rights to be universal, and thus the literature on universalism is rich enough to be divided into two areas: philosophical universalism and positivist universalism. This section will treat, and reject, each in turn.

questionable rights, creating a workable, culturally sensitive list of universal rights. Schooley, supra note 20, at $682-90$.

23. Universalists argue that (Western) notions of human rights are universally applicable. Schooley, supra note 20, at 691-98.

24. Feminists concentrate on deconstructing the male bias that exists, of ten both in the local cultures and in the international human rights laws themselves. Schooley, supra note 20, at 698-704.

25. In the beginning of Schooley's article, she claims that Communitarianism "offers an alternative framework that focuses on group privileges." Schooley, supra note 20, at 679. Yet, it is unclear why Schooley feels that " $[w]$ hen seeking to facilitate discussion across cultural lines without falling prey to the alienation of universalism, the communitarian model, which views people in terms of their relationship to the group, is the more effective model for international dialogue." Id. at 705. Similarly, she claims that "[c]ommunitarianism 'engages' with cultures excluded by liberal rights language" and that "[u]nlike cultural relativism, it does not discard universal standards." Id. at 711. But, Schooley does not explain why a preference for group privileges provides an alternative to cultural relativism or universalism, except perhaps that it would be part of a general goal of revising "international norms to remove the presuppositions that all communities are western liberal." Id. at 714; see id. at 704-14. In this note, I will attempt to expand where Schooley left off. Developing the concept of reverse moderate relativism, which searches for shared values beginning with a preference for local instead of international ones, I will provide four examples of areas in which international norms are moving closer to local norms. See this author, Part IV, infra at 14. Schooley is correct that communitarianism is one of these ways, but where she remained vague I will attempt to explain why this is so. See this author, Part IV(B)(2), infra at 14.

26. Schooley, supra note 20 , at $679-82$.

27. Id. at $682-90$.

28. I do not examine feminism because, contrary to Schooley, I do not view it as a distinct theory of relativism per se. Rather, feminism (the deconstruction of male bias) is present in all of the theories. I do not examine communitarianism because it is unclear exactly how Schooley is using this term. See this author's comments, supra note 25 , at 7 . 


\section{Philosophical Universalism}

Philosophical universalism is the belief that international human rights law can and should "transcend social and cultural idiosyncrasies by grounding moral judgments in universal principles." ${ }^{29}$ Thus, rather than being a solution to the tension between universal human rights norms and local customs, universalism is a rejection that the tension exists at all. The tensions I identified in part II are simply two numerous for this theory to be tenable. It is not possible to ignore these tensions, and it is neo-colonialist to discredit them. Perhaps some daywhen cultures have mixed for many more millennia and human rights norms have been continuously refined-universalism will be viable, but that day is nowhere in sight.

\section{Positivist Universalism}

Positivists constitute another branch of the universalist school: by adopting strict legal positivist interpretations of a state's human rights obligations based on nothing more than the combination of its treaty ratifications and reservations, ${ }^{30}$ positivists confidently champion universality. They argue that as long as a state has made reservation to any provisions that it cannot meet, there is no threat to universalism. In fact, they contend, reservations to human rights treaties support universalist ambitions by maximizing membership in such treaties." Cook notes that "[r]eservations offer a middle path by which a convention's universality can be served by selective amendments that permit a state party to adjust its relations with other states parties while preserving ... [a human rights treaty's] integrity. ... Reservations may be ... seen as a limited concession that may be yielded in order to build an integrated world order." ${ }^{\text {,2 }}$ Indeed, reservations to human rights treaties, both by Islamic and Western states, are common. ${ }^{33}$

29. Schooley, supra note 20 , at 692.

30. See Cook, supra note 4, at 684 ("Reservations may be viewed in different ways. For example, reservations may be seen as meeting the claim of sovereign states to bargain for treaty membership on their own terms, or as a limited concession that may be yielded in order to build an integrated world order."); ANTONIO CASSESE, INTERNATIONAL LAW 130 (2001) (describing state reservations and concluding that such a "legal regime has the great merit of allowing as many States as possible to take part in treaties that include provisions unacceptable to some of them").

31. Cook, supra note 4, at 711 ; see also id. at $680-81$ ("It is proposed . . . that the universal aspiration of the Convention [The International Convention on the Elimination of all forms of Discrimination Against Women] compels recognition that states parties are located at different points on the road to achievement of the Convention's obligation of result and that they may progress at different rates.").

32. Id. at 683-84.

33. See generally id.; Venkatraman, supra note 4. The most commonly reserved-to human rights treaty, by Islamic and non-Islamic states alike, is the Convention on the Elimination of All Forms of 
The strongest critique of positivist universalism is that its acceptance undermines the whole system of human rights: If any given state (Islamic, Western, or otherwise) can easily ratify all human rights treaties merely by crafting reservations to relevant articles where state- and treaty-norms are in tension, human rights treaties could quickly reach universal ratification without ever effecting change at the domestic level. A false universalism is created and espoused in those treaties, ratified widely but followed nowhere. ${ }^{34}$

\section{B. Strict Cultural Relativism}

Strict cultural relativism is the belief that "local cultural traditions ... properly determine the existence and scope of ... [human] rights enjoyed by individuals in a given society ... [and] that no trans-boundary legal or moral standards exist against which human rights practices may be judged acceptable or unacceptable." 35 Strict cultural relativists "oppose any discussion of international human rights consensus as an affront to culture."36

Strict cultural relativism has been criticized as self-contradictory: the notion that all values are culturally relative, the belief in "the equal dignity and worth of all cultures," or "the equal right of all peoples to participate in the formation of international law" are themselves culturally shaped value judgments, which would be void under the cultural relativist's own theory. There is no reason for cultural relativists to accept these starting points as universal in order to support a doctrine which denies the legitimacy of

Discrimination Against Women, Dec. 18, 1979, 1249 U.N.T.S. 13 (entered into force Sept. 4, 1969) (hereinafter CEDAW]. See Cook, supra note 4, at 644; Venkatraman, supra note 4, at 1955 ("In terms of sheer number of reservations, the Women's Convention has faced an extraordinary amount of opposition. Many of the reservations are substantive. Further, the Convention has been subject to considerable political debate over its alleged cultural and religious hegemonistic [sic] character.") (citations omitted). Despite the voluminous commentary on Islamic reservations to this treaty, it bears mentioning that many reservations to CEDAW are also entered by Western nations. For example, at the time of Cook's article, there were five reservations to Article 16 from Islamic nations (Egypt, Iraq, Bangladesh, Tunisia, and Turkey) and eight from non-Muslim states (Thailand, United Kingdom, Brazil, France, Republic of Korea, Ireland, Luxembourg, and Mauritius). Cook, supra note 4 , at 716 . Although of varying breadth, there were thus more reservations to CEDAW article 16 entered by non-Islamic states than there were by Islamic states, despite all the talk about the incompatibility of Islam and human rights by commentators based on this article of the Convention. The fact that CEDAW is heavily reserved from by all nations supports the moderate cultural relativist argument. See, author's comments, infra note 40, at 10; see also Cook, supra note 4, at 663-73.

34. The positivist view that a State is subject only to its ratified treaty obligations less reservations has been considerably weakened since both the European Court of Human Rights and the Human Rights Committee have taken the view that reservations contrary to a treaty's object and purpose are void. CASSESE, supra note 30 , at $130-31$.

35. Fernando R. Tesón, International Human Rights and Cultural Relativism, 25 VA.J. INT'L L. 869 , 870-71 (1985).

36. Schooley, supra note 20 , at 678 . 
universals. ${ }^{37}$ From a normative human rights perspective, strict cultural relativism is also questionable because it has little to no support in human rights conventions. The only treatment of strict cultural relativism in a human rights convention is article 63(3) of the European Convention on Human Rights, which says that " $[t]$ he provisions of this Convention shall be applied in [colonial territories] with due regard, however, to local requirements." 38 A strict cultural relativist reading of this provision has been rejected by the European Court of Human Rights in Tyrer v. United Kingdom, where the local custom of corporal punishment was at issue. ${ }^{39}$

Thus, because of the logical self-contradiction inherent in strict cultural relativism, and because of the virtual complete lack of support for strict cultural relativism in the human rights discourse, strict cultural relativism fails as a paradigm to conceptualize the universality discourse.

\section{Moderate Cultural Relativism}

Moderate cultural relativism is the belief that human rights are culturally relevant to a degree, but that there exists some minimum core of rights that can be considered universal. ${ }^{40}$ Thus, moderate cultural relativists concentrate on the

37. Guyora Binder, Cultural Relativism and Cultural Imperialism in Human Rights Law, 5 BufF. HuM. RTS. L. REv. 211, 214-15 (1999).

38. Tesón, supra note 35, at 877 (citing Convention for the Protection of Human Rights and Fundamental Freedoms, Nov. 4, 1950, art. LXIII, para. 3, Europ. T.S. No. 5, http://www.pfc.org.uk/legal/ echrtext.htm (last visited Oct. 10, 2003).

39. The court interpreted the word "requirement" narrowly, and found that corporal punishment was not "required" to maintain law and order, and thus did not fit in to the exception. Tesón, supra note 35, at 877 (citing Tyrer v. United Kingdom, Eur. Ct. H.R. 5856/72 (ser. A) (1978)). As an additional defect, Schooley notes "a logical flaw in the cultural relativist argument. When stating that all cultures differ, the relativist makes a descriptive statement; however, when the relativist draws the conclusion that persons should not make cross-cultural judgments the relativist makes a normative statement. Thus, the relativist contradicts his own premise." Schooley, supra note 20 , at 682 . For perhaps the most scathing critique of strict cultural relativism (without actually bolstering universalism), see generally Tesón, supra note 35. Tesón divides cultural relativism into three branches: descriptive relativism, under which "different societies have different perceptions of rights and wrong," metaethical relativism, which holds that "it is impossible to discover moral truth," and normative relativism, which "asserts that persons, depending on their cultural attachments, ought to . . have different rights." Id. at 886-87. The first two of Tesón's theories are direct applications of philosophical relativism, and the third, although invoking norms, is based on a philosophical relativist rationale. According to Tesón, "[n]ot only does positive international law fail to provide any basis for the relativist doctrine, but the underlying philosophical structure of relativism also reveals profound flaws." $I d$. at 894 . He believes that "cultural relativism exhibits strong discriminatory overtones and is to a large extent mistaken in its factual assumptions." Id. at 898.

40. Schooley, supra note 20 , at $678-79$ ("While maintaining a relativist perspective on the world, moderate cultural relativists accept a need for some form of minimal standard of protection that must be evaluated and legitimized through culture"). It bears mentioning that Teson's cultural relativism is only a critique of strict cultural relativism, and would not apply to moderate cultural relativism. See Tesón, supra 
two tasks of defining the minimum core rights and investigating possibilities for the enlargement of this group of core norms, through reinterpretation of both local and international norms. This camp has been made famous in the Islamic context through the influential Islamic scholar Abdullahi Al An-Na'im, and his mentor Mahmoud Mohamed Taha. ${ }^{41}$ According to An-Na'im and Taha, "Shari' a reflects a historically-conditioned interpretation of Islamic scriptures in the sense that the founding jurists had to understand those sources in accordance with their own social, economic, and political circumstances." 42 An$\mathrm{Na}$ 'im therefore advocates a constructive interpretation of primary sources based on modern conditions, ${ }^{43}$ all the way to the point of expanding the scope of ijtihad (Islamic legal reasoning) "to enable modern Muslim jurists ... to substitute previously enacted texts with other, more general, texts of Qur' an and Sunna [the two principle textual sources of Islamic Law] despite the categorical nature of the prior texts." 44 Defending this technique on the grounds that "the proposed new rule would also be based on the Qur'an or Sunna, albeit on a new

note 35 , at 870 . Tes6n's main thesis is that "[i]f there is an international human rights standard - the exact scope of which is admittedly difficult to ascertain - then its meaning remains uniform across borders ... [and] if there is a possibility of meaningful moral discourse about rights, then it is universal in nature and applies to all human beings despite cultural differences." Id. at 873. In fact, this thesis is practically the dictionary definition of moderate cultural relativism, admitting of some universal rights but remaining cautious of the scope of universality. And, just as the line between strict cultural relativism and moderate cultural relativism is often blurred, so is the line between positivist universalism and moderate cultural relativism. I have argued above that positivist universalists are mistaken to champion universalism based on treaty reservations. See this author, Part III(A)(2), at 8 . In some cases, however, treaty reservations may support the theory of moderate cultural relativism. For example, the fact that CEDAW is heavily reserved-to by all nations supports moderate cultural relativist argument. To the moderate cultural relativist, the high proportion of reservations to CEDAW by both Islamic and non-Islamic states shows that some core minimal set of shared universal rights does exist, but that CEDAW exceeds it. See Cook, supra note 4, at 663-73. The two main ways in which CEDAW offends both Islamic and Western states' sense of acceptable international regulation is its regulatory reach into the private sphere and its breadth to include "all forms" of discrimination against women.

The Women's Convention is a brand apart from other treaties because it seeks to regulate not only state, but also private, nongovernmental action. More specifically, the Women's Convention seeks to influence cultural values that may prescribe the traditional roles of men and women in marriage, family relations, and other situations that are fertile ground for sexual stereotypes. It is precisely this state duty to counter discrimination in private life that renders the Women's Convention a dynamic, as well as controversial, instrument of human rights.

Venkatraman, supra note 4, at 1950-51.

41. Schooley, supra note 20, at 682-83.

42. An-Na'im, supra note 4 , at 46.

43. Id. at 47 ("Working with the same primary sources, modern Muslim jurists might shift emphasis from one class of texts to the other, and interpret the previously enacted texts in ways consistent with a new understanding of what is believed to be the intent and purpose of the sources.").

44. Id. at 49. 
interpretation of the text," ${ }^{45}$ An-Na'im has employed this approach to justify various human rights through Islamic Law, such as non-discrimination, ${ }^{46}$ freedom of thought, conscience, and religion, ${ }^{47}$ abolition of apostasy, ${ }^{48}$ and equality of the sexes. ${ }^{49}$

Of the three theories explained in this section, An-Na'im's moderate cultural relativism is certainly the best. Contrary to universalism, it admits that notions of rights do differ between cultures, a reality I made readily clear in Part II. Contrary to strict cultural relativism, however, it does not discount the amount to which certain notions of rights are shared. It occupies a solid middle ground between these two extreme theories. Furthermore, at least on its face, moderate cultural relativism's goal of re-interpreting texts in light of modern conditions is consistent with the Islamic legal methods of ' $U r f$ (considerations of custom), ${ }^{50}$ Maslahah Mursalah (considerations of public interest), ${ }^{51}$ Istihsan (considerations of equity), ${ }^{52}$ and changed circumstances, ${ }^{53}$ "whose apparent aim is to reverse the negative or unanticipated effects of a strict formalist reading ... and justify changes in doctrine." 54

45. Id.

46. According to An-Na'im, "in numerous verses the Qur'an speaks of honor and dignity for 'humankind' and 'children of Adam,' without distinction as to race, color, gender, or religion." Id. at 47. An$\mathrm{Na}$ ' im accomplishes this by interpreting "baniy" in the Holy Qur' an 17:70 as both male and female children, creating a verse in which God honors all "children of Adam." An-Na'im, supra note 4, at 47-48 n.149. He finds further support for equality in the Holy Qur'an 49:13, which he translates/interprets as follows: " $O$, humankind, We [God] have created you into male and female, and made you into peoples and tribes so that you may be acquainted [and cooperate] with each other." Id.

47. Id. at $48 \mathrm{nn}$.150-51 (noting several Qur'anic verses supporting freedom of thought, conscience, and religion, which "have been either de-emphasized as having been 'overruled' by other verses which were understood to legitimize coercion, or 'interpreted' in ways which permitted such coercion") (citing, inter alia, Holy Qur'an 2:256 ("Let there be no compulsion in religion: Truth stands out clear from error . . .") deemphasized to Holy Qur'an 9:29 ("Fight those who believe not in God and the Last day, nor hold that forbidden which hath been forbidden by God and His Apostle, nor acknowledge the Religion of Truth, [even if they are] of Ahl al-kitab, until they pay Jizya with willing submission, and feel themselves subdued")).

48. Id. at 48 (citing A. RAHMAN, PUNISHMENT OF APOSTASY IN ISLAM (1972)).

49. An-Na'im, supra note 4, at 48 (arguing that qawama, or guardianship and authority of men over women, based on Holy Qur'an 4:34, is untenable when interpreted in light of modern conditions, since "neither of the conditions-advantages of physical might or earning power-set by verse 4:34 as the justification for the qawama of men over women is tenable today").

50. Mohammad Hashim Kamali, PRINCIPLes of ISLAmic JURISPRUdenCE 282-95 (rev. ed. 1991); see also Sayeh \& Morse, supra note 4, at 317.

51. KAMALI, supra note 50, at 267-81; see also Sayeh \& Morse, supra note 4, at 317.

52. KAMALl, supra note 50, at 245-64.

53. See Sayeh \& Morse, supra note 4 , at 317.

54. Sherman A. Jackson, Fiction and Formalism: Towards a Functional Analysis of Usûl al-Figh, in STUDIES IN ISLAMIC LEGAL THEORY 177, 195 (Bemard G. Weiss ed., 2002). 
But, although An-Na'im's approach is prima facie valid from the perspective of these Islamic legal techniques, it should be analyzed from the perspective of Professor Sherman A. Jackson's theory of a New Legal Formalism in Islamic Jurisprudence. Jackson analyzes the Shafi'i jurist Imam al-Haramayn al-Juwayni's argument that non-Muslims should not serve as "executive viziers," noting that "Al-Juwayni began with a set of presuppositions, among them the belief that it is not good for Jews and Christians to serve as executive viziers. From here, he would go on to validate this view by tapping into the rhetorical force supplied by usul al-fiqh [the science of source methodology in Islamic jurisprudence] and the legal master-narrative." 55 Just as Al-Juwayni began, and sought to validate, a set of assumptions in Jackson's analysis, so too does An-Na' im. For An-Na'im, this set of presumptions is the superiority of international human rights. For example, Schooley notes that "although An-Na'im advocates a cross-cultural dialogue to define 'rights,' he actually adopts as 'rights' those already considered the norm in international law and advocates that the Shari'a be reformed to meet these standards. This approach seems conceptually inconsistent with An-Na'im's cultural legitimacy theme." 56 Thus, despite its relative strength in comparison to the other camps, the An-Na'im school suffers a major flaw in its inherent international bias. Although it is possible under An-Na'im's approach to reach common ground with international norms on some issues by a plausible reading of local texts, such a theory based on international norms is likely to offend local culture frequently, ${ }^{57}$ and is dangerously neo-colonialist. It is this ignorance of perspective that is the cornerstone of my theory of reverse moderate relativism, developed in the rest of this note.

\section{REVERSE MODERATE RELATIVISM: A DIFFERENT PERSPECTIVE ON THE DEBATE}

\section{A. Introduction: False Universalism and the Flaw of Perspective}

Although there is some merit to any of the above views, and the moderate cultural relativist theory of Abdullahi Al An-Na'im has gained considerable

55. Id. at 196-98.

56. Schooley, supra note 20, at 690; see also Sayeh \& Morse, supra note 4, at 331 (noting that the United Nations Declaration on the Elimination of Discrimination Against Women approaches human rights protection "from a Western perspective ... [which] ignores an important truth: There exist in non-Western countries conceptions of human dignity which are as valid as those engendered in the West.").

57. Even An-Na'im himself admits this, prefacing his work with the caveat: "These [constructivist] views, however, are appreciated by only a tiny minority of contemporary Muslims. To the overwhelming majority of Muslims today, Shari'a is the sole valid interpretation of Islam, and as such ought to prevail over any human law or policy." An-Na'im, supra note 4, at 21. 
attention, all of these theories contain a fundamental flaw: perspective. In other words, each proceeds on the assumption that any conflict between Islamic law and human rights norms is best resolved by a modification or reinterpretation of the Islamic norms, while the international ones remain the static. In setting up the international norms as neutral, this assumption validates international norms as a standard to be achieved by other norms, such as Islamic Law. This is as neo-colonialist as it is patronizing, and is particularly open to scrutiny in light of the fact that Islamic and other non-Western states did not have equal bargaining power in the creation of the international norms. ${ }^{58}$ In attempting to spawn universal consensus on rights based on a gravitation towards a Western-centered conception of human rights, moderate cultural relativism (and certainly universalism) do nothing more than re-enforce the (Western) oppressor view.

The concept of equality, which is all-too-often viewed through the lens of the oppressor, provides a fertile ground to explore this reality. For example, commentators have forcefully criticized procedural equality as over-simplistic when operating in a world where one group already holds the position of the accepted neutral. In his book White, Richard Dyer argues that " $\mathrm{t}] \mathrm{h}$ here is no more powerful a position than that of being 'just' human. The claim to power is the claim to speak for the commonality of humanity. Raced people can't do that-they can only speak for their race." 59 Professor Sherman Jackson notes that "[w]hiteness, in other words, reigns supreme precisely because it is invisible; and because it is invisible, whites enjoy the status of being 'just people' in the most generic sense." ${ }^{, 00}$ This is exactly what occurs in the prevalent universality paradigms: by establishing human rights as the "neutral"

58. Schooley, supra note 20 , at $680-81$.

It should not be forgotten that the San Francisco Conference which established the United Nations in 1945 was dominated by the West, and that the Universal Declaration of Human Rights was adopted at a time when most Third World countries were still under colonial rule. Thus to argue that human rights has a standing which is universal in character is to contradict historical reality

Id.; but see Tesón, supra note 35, at 897.

[E]ven if the law of human rights was originally conceived as an ideological tool [of the West] against communism, today human rights have achieved a universal scope and inspire the struggle against all types of oppression. In other words, the circumstances surrounding the origins of human rights principles are irrelevant to their intrinsic value and cannot detract from their beneficial features. (emphasis added).

Id. (emphasis added).

59. Sherman A. Jackson, Islam and Affirmative Action, 14 J.L. \& RELIGION 405, 411 (1999) (citing RICHARD DYER, WHITE 2 (1997)).

60. Id. at 411 . 
norms to be achieved, all other local norms are subjugated before the process of reconciling norms even begins.

Similarly, the Western notion of absolute equality of the sexes could be criticized because, although the equality standard to be strived for is absolute, the benchmark is masculine. In other words, the Western conception of equality among the sexes means letting women live in a masculine world like men. Just as the tacitly accepted neutral standard for race is white, the unspoken neutral standard for sex is male. Against this notion, several Islamic states have "emphasize[d] the concept of complementarity of the spouses ..., ... marshaling a 'separate but equal' argument, portraying the Islamic concept of women's equality in terms of complementary rights, [and] 'according women rights equivalent to the rights of their spouses so as to ensure a just balance between them." "61

These two substantive examples show that the Western notion of absolute equality is undermined by its ignorance of the neutral benchmark to which that absolute equality is expected to gravitate. As long as the neutral benchmark is the oppressor (white, male), absolute equality will be insufficient. The same can be said for human rights in general: as long as the neutral standard for gravitation is (western) human rights, any universalizing theory of human rights will have the effect of subjugating local norms to international norms in an effort to standardize them. Thus, a new theory about the universality of human rights is in order, which I will call reverse moderate relativism and elaborate in the following section.

\section{B. Support for Reverse Moderate Relativism in Islamic Law}

On a general level, the tacit acceptance of the oppressor view as "neutral" was critiqued by the Critical Legal Studies (CLS) movement born at Harvard in the 1970s. ${ }^{62}$ Like the legal realists of the thirties, CLS questioned the mechanics of formalism, asserting that interpreters of texts necessarily include their own beliefs in any supposedly rigid and formalistic interpretation

61. Venkatraman, supra note 4, at 1961 (citing Cook, supra note 4, at 704). The two most outspoken States in this regard by way of reservations to CEDAW Art. 16 have been Egypt and Morocco. Egypt's reservation to article 16 (elimination of discrimination against women in all matters, public and private, involving marriage and the family) states Egypt's adherence to that article

must be without prejudice to the Islamic Shari'a provisions whereby women are accorded rights equivalent to those of their spouses so as to ensure a just balance between them. This is ... in view of the fact that one of the most important bases of ... [marital] relations is an equivalency of rights and duties so as to ensure complementarity [sic] which guarantees true equality between the spouses and not a quasi-equality that renders the marriage a burden on the wife.

Cook, supra note 4, at 704 (first brackets added).

62. Jackson, supra note 54 , at 182. 
process. ${ }^{63}$ But, the CLS movement launched the greater critique that, by the addition of such personal beliefs and biases, ostensibly neutral interpreters create a "consciously preserved system of defending the interests of the powerful." " Professor Sherman A. Jackson has since applied the CLS critique to usul al-fiqh. ${ }^{65}$ Just as the CLS movement has criticized American law for tacitly accepting and furthering the oppressor view, and just as Jackson has applied this same theory to Islamic law, so must the theories on the universality of human rights be understood and examined in light of the CLS critique. To accomplish this end, I propose a new theory on the universality of human rights is in order, which I will call reverse moderate relativism.

Like moderate cultural relativism, reverse moderate relativism proceeds on the premise that universality of human rights is impossible, but that some core set of rights or standards may exist which are universally applicable. But, reverse moderate relativism searches for these core shared values in reverse fashion from moderate cultural relativism: instead of starting with the international value as the neutral benchmark and reinterpreting local law to draw it closer to the international norm, reverse moderate relativism takes a given local law as the neutral standard, and exposes ways in which international law has drawn closer to that standard. Thus, in the remainder of this note, I will attempt to refocus the debate in the reverse moderate relativist model, considering four possible areas where Islamic law and human rights law are becoming more similar by way of a Western doctrinal gravitation towards an Islamic standard. While this approach does not aim to be exhaustive nor causative ${ }^{66}$ such examples provide a much-needed respite from the excess of literature on the universality of human rights written in the Westerninternational-neutral paradigm.

\section{Islam's Zakat and the International Right to Social Security}

In the Islamic faith, the duties to God are encompassed in the "five pillars of Islam." 67 These include the profession of faith (shahada), prayer (salat)

63. Id. at $181-82$.

64. Id. at 182.

65. Id. at $196-98$.

66. By "causative," I completely accept that the gravitations described are not the result of some reversal of tacit power from international to local norms which caused these new gravitations towards certain Islamic standards. Rather, the gravitations represent areas where, quite independently, the international standard has begun to shift towards a long-standing Shari'a standard. Despite this lack of causation, such changes are worth pointing out when they happen. Perhaps if they are pointed out enough, such a power shift of neutral benchmarks may even become realistic.

67. Schooley, supra note 20, at 668 n.94 (citing JOHN L. ESPOSITO, ISLAM THE STRAIGHT PATH 90$93(1988))$. 
facing Mecca five times a day and a prayer in a community on Friday at noon, almsgiving (zakat), fasting during the month of Ramadan, and making a hajj pilgrimage to Mecca at least once in a lifetime if physically and financially able. $^{68}$ This section will examine the zakat from a reverse moderate relativist standpoint.

The payment of Zakat by Muslims helps to "support the poor, orphans, and widows, [and] to free slaves and debtors." has varied throughout time and from region to region, ${ }^{70}$ and the extent that zakat actually serves as a wealth-redistributing device is open for debate. ${ }^{71}$ But, an

68. Id.; see also Hamid M. Khan, Nothing is Written: Fundamentalism, Revivalism, Reformism, and the fate of Islamic Law, 24 MICH. J. INT'L L. (forthcoming 2003).

69. Schooley, supra note 20, at $668 \mathrm{n} .94$ (citing ESPOSITO, supra note 67, at 92); see also Arzt, supra note 4, at 207.

Islam emphasizes the obligation of the state to provide sufficient levels of food, clothing, and housing. The poor must not be required to beg. Thus, the public treasury must contain a fixed portion for the needy, the aged, and orphans. Every Muslim has the duty of zakat, to help the poor.

Id.

70. Zakat has a long and complex history. It is generally considered a wealth tax, but could be considered an income tax. Timur Kuran, Islamic Redistribution Through Zakat: Historical Record and Modern Realities, in POVERTY AND Charity IN MIDDle EASTERn CONTEXTs (Michael Bonner, et al., eds.) (forthcoming) ("Zakat was initially a wealth tax, and to this day it is generally defined as such. . . But the decision to limit collections to a share of 'apparent wealth' turned the obligatory levy into what we would now call an income tax."). According to Professor Kuran, at the time of the Prophet Mohammed, "all taxes were called zakat," including customs duties, but the precise scope of zakat has since narrowed considerably. Id. at 8 . Furthermore, at any one time, Zakat often differs substantially from one region to another. Kuran notes that "[i]n every country with a government-sponsored or -operated zakat system (including Malaysia, Pakistan, and Saudi Arabia), rates, exemptions, collection methods, and disbursement patterns have varied over time; and variations across countries are ... sharp." Id. at 1.

71. See id. at 2.

[P]overty alleviation is but one of the objectives that zakat was initially meant to serve. Indeed . . z zakat was not designed solely, or even primarily, to redistribute wealth in the manner of a progressive tax scheme, or as an antidote to poverty in the manner of a welfare program. Although the Qur'an and the Sunna . . contain prescriptions consistent with using zakat to transfer wealth to the poor, the system's past applications are compatible with any number of other objectives, even redistribution in favor of the rich.

Id. at 2. Kuran's point, that zakat does not always benefit the poor and may benefit the rich, repeated many times over in his paper, is founded on the fact that the rich could potentially be among the eight possible beneficiaries of zakat (the poor, the needy, zakat administrators, potential converts and Muslims who might yet renounce Islam, manumitted slaves, debtors, people fighting for God, and wayfarers). Id. at 6 (citing Holy Qur'an 2:177, 2:217, 4:8, 9:60, 24:22). For example, according to Kuran, any rich Muslim who is fighting for Islam could "demand assistance," and "even the wealthiest traveler could make a case for having the state treasury cover his expenses." Kuran, supra note 70, at 6 . This is a weak critique. Although Kuran repeatedly emphasizes that redistribution back to the rich is possible, he advances very little evidence to show it is common, or likely. Assuming zakat often functions as an effective wealth re-distribution system, it should 
analysis of Islamic Law is concerned about norms, not facts or history. Normatively, Kamali notes that "[t]he Qur' an often indicates the rationale of its laws either explicitly or by reference to its objectives. ... [T] [Te rationale of $z a k a h$ is to prevent the concentration of wealth in a few hands, which is clearly stated in the Qur'an (al-Hashr, 59:7)."72 Similarly, Qur' an 51:19 states "And those who seek help and are needy have due share in their wealth." least a dozen Qur'anic passages have been interpreted as instructing believers to establish foundations serving religious or charitable purposes."74 Thus, through zakat and other social equalization measures, ${ }^{75}$ Islam has since the time of the Prophet placed a heavy concern on wealth redistribution and the elimination of poverty by creating individual duty incumbent on each Muslim to surrender a percentage of his or her income to the needs of others.

The importance of social equalization and wealth redistribution is also recognized in human rights, particularly in the human rights discourse on economic, social, and cultural rights (hereinafter "ESC rights") ${ }^{76}$ For example, the International Covenant on Economic, Social, and Cultural Rights (hereinafter "ICESCR") claims a right to social security, the right to an "adequate

not be overly criticized simply because it sometimes redistributes wealth back to the rich. Few, if any, wealth re-distributing systems outside of Sherwood Forest take all wealth from rich hands and put it in poor hands. In a typical Western model of taxation for social services, for example, the poor stand to benefit more from some social programs (welfare, unemployment) but everyone, even the rich, benefit from others (police, fire protection). The same could be said about Kuran's concern that zakat could take wealth from the poor, such as small farmers. $1 d$. at 19 . While this is possible (although un-substantiated), under a properly-functioning zakat system that same small farmer would also be the recipient of zakat if she is truly in need. Thus, much like income tax rebates for United States citizens on welfare, the zakat system could self-correct for Kuran's concern.

72. KAMALI, supra note 50, at 217. Kuran, however, has left normative analysis of the law on zakat, for a factual analysis based on hypotheticals instead of facts. See Kuran, supra note 70, at 10 ("We have no way of knowing [how much zakat benefited the poor]. The available sources have not been studied for quantitative indicators, and in any case relevant documentation is very limited.").

73. Arzt, supra note 4, at 208 (citing Qur' an 51:19).

74. Timur Kuran, The Provision of Public Goods under Islamic Law: Origins, Impact, and Limitations of the Waqf System, 35 LAW \& SOC'Y REV. 841, 844-45 (2001).

75. Kuran notes that "the Islamic inheritance system, which divided estates among extended relatives, was certainly a more potent equalizing instrument than practices undertaken to meet the zakat requirement." Kuran, supra note 70 , at 11.

76. See, e.g., International Covenant on Economic, Social, and Cultural Rights Dec. 16, 1966, 993 U.N.T.S. 3 [hereinafter ICESCR].

77. Id. at art. $\mathrm{XX}$, at 7 ("The States Parties to the present Covenant recognize the right of everyone to social security, including social insurance."). 
standard of living,"78 and the rights to be free from hunger. ${ }^{79}$ But, whereas zakat is a concrete duty upon Muslims which falls under criticism only because it can lead to perverse results or is not always followed, ${ }^{80} \mathrm{ESC}$ rights have not even reached the preliminary level of creating concrete duties. ${ }^{81}$ In fact, even the extent to which ESC rights are individual rights at all is highly debatable, as can be evidenced by the lack of an Optional Protocol to the ICESCR along the lines of the Optional Protocol individual complaints mechanism that exists for the International Covenant on Civil and Political Rights. ${ }^{82}$ No such Optional Protocol exists because ESC rights are considered by many human rights commentators to be un-justiciable. ${ }^{83}$ The two largest human rights nongovernmental organizations have also until recently refused to consider them. ${ }^{84}$ Thus, from a strictly normative standpoint, zakat norms create quantifiable

78. Id. at art. XI, para. I, at 7 ("The States Parties to the present Covenant recognize the right of everyone to an adequate standard of living for himself and his family, including adequate food, clothing and housing, and to the continuous improvement of living conditions.").

79. Id. at art. XI, para. 2, at 6.

80. See Kuran, supra note 70, at 1-8, 19; this author's comments, supra notes 70-71, at 17-18.

81. Kitty Arambulo, Essay, Drafting an Optional Protocol to the International Covenant on Economic, Social and Cultural Rights: Can an Ideal Become Reality? 2 U.C. DAVIS J. INT'L L. \& POL'Y 111 , 116 (1996) (noting the "vagueness of the formulation of economic, social and cultural rights, and the opaque normative contents of those rights"). Furthermore, it is interesting to note that social equalization under ESC rights concentrates only on deprivation, whereas some have argued that Islam is also concerned with overaffluence. Arzt comments that "[j]ust as extreme poverty leads to non-belief, riches are to be shunned, because they offer enticement to sin." Arzt, supra note 4, at 208 . Although certain schools of thought which influenced the drafting of human rights conventions (socialism, communism) are equally antithetical to individual wealth, from a normative standpoint the text of the ICESCR never takes any stand against wealth. Rather, it takes a stand against poverty and deprivation, while staying neutral on wealth. Thus, whereas zakat is, according to Arzt, concerned about equalization at both the privileged and deprived ends of the spectrum, ESC rights are solely concentrated on the deprivation end.

82. Arambulo, supra note 81, at 128.

83. Id. at 125 .

84. Moreover, Amnesty International, the world's largest human rights non-governmental organization (hereinafter NGO), had excluded ESC rights from its mandate until a recent change in 2001. Change in the Air for Al: The 2001 International Council Meeting Sets a New Course for the Future of AI, THE WIRE, Oct. 2001, http://web.amnesty.org/80256A3B00688CC9/0/77AACFCBED 7901C880256AD200370C62? Open\&Highlight $=2$,mandate (last visited Oct. 3, 2003); This change came against bold criticism that Amnesty International's mandate should stay fixed. See Katherine E. Cox, Should Amnesty International Expand Its Mandate to Cover Economic, Social, and Cultural Rights? 16 ARIZ. J. INT'L \& COMP. L. 261 (1999); Similarly, Human Rights Watch, the world's second largest human rights NGO, has only recently begun addressing violations of ESC rights, and even this most often occurs when the ESC violations "result from violations of civil and political rights or must be remedied as part of a plan for ending violations of civil and political rights." Economic, Social, and Cultural Rights, (Human Rights Watch, New York, N.Y.), at http://www.hrw.org/esc/ (last visited Sept. 27, 2003). To its credit, Human Rights Watch, in the early 1990s, took a strong stance that ESC rights are fundamental to effective civil and political rights. See generally Human Rights Watch, INDIVISIBLE HuMan Rights: THE RELATIONSHIP OF POLITICAL AND CIVIL RIGHTS TO SURVIVAL, SUBSISTENCE AND POVERTY (1992). 
obligations on the part of each individual Muslim, while ESC rights create only ambiguous, general rights, with no individual duties. ${ }^{85}$

In recent years, however; interest in ESC rights has increased. A growing number of commentators are now arguing for the justiciability of ESC rights, ${ }^{86}$ and serious efforts are underway to create an Optional Protocol to the ICESCR which would render the debate over ESC rights much more individualized ${ }^{87}$ and specific. ${ }^{88}$ The debate is finally moving "from the legal character and validity of economic, social and cultural rights, to the problem of their application before quasi-judicial bodies." ${ }^{\text {99 }}$

In the area of wealth equalization, the rules of zakat, although not always effective, have been more rigid, quantifiable, and individualized than anything possibly conceived in the domain of ESC rights. With the growing interest among ESC rights commentators to further specify and individualize ESC rights, reverse moderate relativism demands nothing more than that those commentators recognize that such movement would be towards a standard that is more Islamic. Reverse moderate relativism does not imply that Islam influenced or caused this change, ${ }^{90}$ but rather attempts to refocus the universality debate in a more objective light, acknowledging that no ideology has all of the right answers or should ever be considered a neutral, benchmark standard.

85. Certainly, if one were to leave normative judgment, it would perhaps be even easier to make the case that ESC rights, and human rights in general, have not led to tangible change any more than zakat. For the most convincing analysis yet, see Oona A. Hathaway, Do Human Rights Treaties Make a Difference?, 111 YALE L.J. 1935 (2002) (arguing based on extensive empiracal analysis that human rights compliance of states decreases after ratifying human rights treaties). However, in this note I confine the analysis to the law itself, both of human rights and of Islam.

86. Arambulo, supra note 81, at 129-31.

87. Id. at 133 (noting the "quasi-judicial character of the proposed Optional Protocol to the ICESCR").

88. According to the ICESCR, the adoption of [an Optional Protocol to the ICESCR] . . would greatly enhance the understanding of economic, social and cultural rights in general for the following reasons: (1) a more detailed complaints procedure would be able to bring relief in concrete cases; (2) the focus on a particular case would provide a framework for inquiry which is otherwise absent in a report on the general situation; (3) the mere possibility that complaints might be brought in an international forum would encourage governments to ensure more effective local remedies with respect to economic and social rights; (4) the possibility of an adverse finding by an international committee would give economic and social rights political salience; (5) the existence of a potential remedy at the international level would provide an incentive to individuals and groups to formulate some of their economic and social claims more precisely; and (6) a complaints procedure would produce a tangible result, which is far more likely to generate interest in and understanding of the Covenant as a whole and of specific issues.

Id. at 127-28.

89. Id. at 134 .

90. Indeed, to the extent that moderate cultural relativists argue that international norms influenced or should influence changing interpretations of local standards, dangerous neo-colonial implications arise, particularly in light of differing levels of participation in the international system. 


\section{The Synergistic Relationship between the 'Umma and the individual in Islam}

This section compares the complex relationship between the individual and the 'umma (Islamic community) in Islam to the historically simple preference for the individual in the Western liberal human rights tradition. After outlining the complex interplay between individual and 'umma in Islam, it argues that the addition of "third generation" rights to the human rights discourse creates, from a reverse moderate relativist perspective, a similar level of complexity between individual and group importance that has long existed in Islam. Although still a legal analysis, this section takes a post-formative approach, relying more heavily on present day legal authorities and less on textual reference. ${ }^{91}$

The status of the individual in Islam is complex, and has at times been over-simplified. For example, Schooley notes that "non-western countries, such as those that are Islamic, define personal identity in connection with one's group membership." "92 carries absolute importance over the individual in Islam. Muhammad 'Amara, an Egyptian religious scholar and author, describes the Islamic balance between individual and group:

Islam doesn't think either that the human being is the supreme being in creation, or that he is indistinguishable from the rest of creation. Man is the representative (khalifa) of God, and human beings have liberties that reflect their nature as God's representatives. These liberties are not absolute, they are bounded. So the individual as civil and social being is free, but all this is limited by the need for the freedom of the society. There has to be a balance between what is good for the individual and good for the group-they are not mutually exclusive. This ... is very different from the Western view where, in the democratic state, the ruling class's interests take precedence; or where, in the authoritarian state, the state's interests take precedence. In Islam, the 'umma's interests take precedence, not those of the ruling class, not those of the state, and not those of the individual.

91. See Sherman A. Jackson, Kramer Versus Kramer in a 10th/16th Century Egyptian Court: PostFormative Jurisprudence between Exigency and Law, 8 ISLAMIC LAW AND SOCIETY 27, 32 (2001) (defining post-formative jurisprudence in these terms and noting that "[b]ecause of disparity in narration on the authority of the early authorities and differences in the way in which subsequent scholars extrapolated from these views, there came to exist a multiplicity of views within a school").

92. Schooley, supra note 20, at 679-80. See also Téson, supra note 35, at 883 ("[T] he concept [that] human dignity implies that high priority should be given to individual choices in ways of life, beliefs and the conduct of public affairs. This concept, however, simple as it is, clearly contradicts many existing ideologies and political arrangements.") (citation omitted). 
So, in this sense, Islam has a moderate view of the indiviual: the individual is free in so far as it is of benefit to the community. ${ }^{93}$

Similarly, according to Salah ed-Din Jorshi, a leading Tunisian religious intellectual, it is incorrect to emphasize the concept of tawhid (unity of belief) and umma to "reinforce the domination of the community over the individual and to encourage conformity." Jorshi notes that:

in Islam the individual exists: on the Day of Judgement, God does not speak with the 'umma, He speaks with each individual. ... So, at one and the same time there is the "umma and there is the individual. And in order to have an Islamic view of freedom, of the individual, of human rights, you have to have a vision of the whole society and also of the rights of the individual. ${ }^{95}$

Thus, rather than a simple superiority of the umma over the individual, as many commentators have attempted to construct, Islam is a subtle balance of interests between them. In his authoritative treatise on Islamic law, Mohammad Hashim Kamali specifically notes that, in some areas "rights of the community and those of the individuals are combined." 96 At times, this combination is weighted toward individual rights, such as:

[r]etaliation (qisas), and blood-money (diyah) of any kind, whether for life or for grievous injury. ... The community is entitled to punish such violations, but the right of the heirs in retaliation and in diyah for erroneous killing, and the right of the victim in respect of diyah for injuries, is preponderant in view of the grievance and loss that they suffer as a result. The guardian (wali) of the deceased, in the case of qisas, is entitled to pardon the offender or to accept a compensation from him. But the state, which represents the commu-

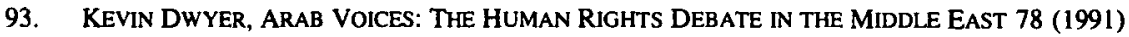
(emphasis added); see also id. at 91:

One of the problems in reconstructing civil society is that in Tunisia, today, everyone is talking of rights and freedoms. But if everyone thinks only of their own rights and freedoms, society will destroy itself, because we are a society that doesn't have everything, that is permeated by scarcity. ... And that's why, at the same time that we talk of rights and freedoms, we have to also talk of duties and obligations, which are essential for us in this historical moment. A society that talks only of rights becomes not a society, but an archipelago.

(quoting personal interview with Salah ed-Din Jorshi, one of Tunisia's leading religious intellectuals).

94. Id. at 90 .

95. Id.

96. KAMALI, supra note 50 , at 349 . 
nity, is still entitled to punish the offender through a $t a$ 'zir punish-

ment even if he is pardoned by the relatives of the deceased. ${ }^{97}$

In other situations, there is debate among the Islamic schools about where the emphasis should fall:

The right to punish a slanderer (qadhif) belongs, according to the Hanafis, to [the] class, by reason of the attack made on the honour of one of its members. Since the Right of God is dominant in qadhf, the victim of this offence (i.e. the maqdhuf) cannot exonerate the offender from punishment. The Shafi' is have, however held the contrary view by saying that qadhf is an exclusive Right of Man and that the person so defamed is entitled to exonerate the defamer. ${ }^{98}$

Regardless of whether one sides with the Hanafis or the Shafi'is on this particular question, it is clear that there is a place in Islamic law for both individual and community interests. It may be true that Islam, and other nonWestern legal and moral traditions, place a heavier emphasis on the community ('umma) ('9 $^{99}$ thestern liberal traditions. But, to say that Islamic law affords no place at all for the individual would be misguided, ignoring the subtle coexistence between individual rights and duties that Jorshi describes, the very real presence of haqq Al-'abd (Islamic private rights) ${ }^{100}$ and active debate among the schools on this very question. Rather, in Islamic law, rights of the individual and duties to the "umma can be said to coexist in a synergistic relationship.

97. Id. at 350 .

98. Id. at 349-50.

99. Kamali's exploration of the numerous haqq Allah is illustrative. See Kamali, supra note 50, at 348-50; this author's comments, infra notes 115-120. Kamali specifically notes that haqq Allah "is called so not because it is of any benefit to God, but because it is beneficial to the community at large and not merely to a particular individual." KAMAL1, supra note 50, at 348-49. In the framework of this note, it should be noted, however, that notwithstanding Kamali's description, most of the principles he categorizes under haqq Allah are more appropriately categorized as duties of the individual to the group than rights of the group itself. See Part IV $(B)(2)(3)$ of this article. Therefore, the norms Kamali mentions are specifically enumerated in the next section on duties. See KaMALI, supra note 50, at 348-50; this author's comments, infra notes 115-120. Perhaps Kamali would argue that there is no difference between duties of the individual and rights of the group- - that the two categories are reciprocal-but at least for this author, it is easier to conceptualize norms such as hajj, jihad, zakat and hudud as individual duties, not group rights. There are some exceptions, which are more easily conceptualized as group rights, including the uqubah qasirah (minor punishments) such as excluding the murderer from the inheritance of his victim, the kaffarat penances, and "community right to mineral wealth or to the spoils of war (ghana'im)." KaMALI, supra note 50, at 349.

100. See KAMALI, supra note 50, at 348-50; this author's comments, infra notes 115-20. 
Human rights law, on the other hand, has historically placed a strong emphasis solely on the individual. For example, Professors Henry Steiner and Philip Alston state in their authoritative text on human rights that "[o]bservers from different regions and cultures can agree that the human rights movement ... stems principally from the liberal tradition of Western thought. . . . [and that] [n]o characteristic of the liberal tradition is more striking than its emphasis on the individual. ${ }^{101}$ Amidst a historical tradition recognizing "first generation" civil and political rights of individuals, ${ }^{102}$ and "second generation" economic, social, and cultural rights of individuals, ${ }^{103}$ it is only recently that the human rights discourse has been enriched, becoming more like the Islamic discourse, to recognize the importance of the group simultaneously with the importance of the individual. Commentary on the importance of groups within society has spawned the most-recent and least developed category of human rights, the socalled "third-generation" human rights (group rights). ${ }^{104}$ This innovative category of "third generation" rights includes such group rights as the right of self-determination, ${ }^{105}$ the right to development, ${ }^{106}$ and the right to peace. ${ }^{107} \mathrm{~A}$ current and highly debated third generation right is affirmative action. ${ }^{108}$ Just as, "in the 1950's, the concept of and need for economic, social, and cultural rights were heatedly debated," now "the opponents of the[se] new rights contend in a similar manner that the third-generation rights are not really legal

101. STEINER \& ALSTON, supra note 1, at 361-62.

102. DAVID J. BEDERMAN, INTERnATIONAl LAW Frameworks 95-96 (2001) (listing "first generation" civil and political rights, such as "freedom from slavery, torture, the right to recognition and equality before the law, freedom from arbitrary arrest and the guarantee of fair criminal procedures, and respect for rights of worship and expression").

103. Id. at 96 (listing "second generation" economic, social, and cultural rights, such as "the right to work, to rest and leisure, to education, and to participation in cultural life").

104. See, e.g., Louis B. Sohn, The New International Law: Protection of the Rights of Individuals Rather Than States, 32 AM. U. L. REV. 1, 48-62 (1982).

105. Id. at 48-52.

106. Id. at $52-56$.

107. Id. at 56-59.

108. See Jason Morgan-Foster, From Hutchins Hall to Hyderabad and Beyond: A Comparative Look at Affirmative Action in Three Jurisdictions, 9 WASH. \& LEE R.E.A.L. J. (forthcoming 2003) (arguing that "as a human right, affirmative action [is] ... a positive duty on a government and it protects group rights"); Louise Mulder, How Positive can Equality Measures Be?, in Non-Discrimination Law: COMParative PERSPECTIVES 65 (Titia Loenen \& Peter R. Rodrigues eds., 1999) (arguing that, by its very nature, affirmative action represents some willingness to acknowledge group rights no matter what the jurisdiction); see also Stephanie Browning, et al., Dueling Fates: Should The International Legal Regime Accept a Collective or Individual Paradigm to Protect Women's Rights?, 24 MiCH. J. INT'L L. 347 (2002) (a recent symposium attracting far less publicity than the affirmative action cases, but also at the University of Michigan and strongly signaling an increased interest in group rights). 
rights but are either political or social principles, or, at best, 'moral' rights."109 Although third generation group rights remain controversial, they have become a regular part of the human rights discourse. From a reverse moderate relativist perspective, human rights has moved more towards an Islamic standard: it has moved away from a juridical structure which focused solely on the individual towards a discourse in which the individual and group are both primary topics of concern.

\section{The Co-existence of Duties and Rights in Islam}

This section begins by analyzing the co-existence of duties and rights in Islam. It then argues that recent movements to emphasize individual duties and responsibilities are another area that, from a reverse moderate relativist perspective, the human rights discourse is approaching an already existing Islamic dialogue.

Some commentators describe Shari'a as if duties held absolute priority over rights. For example, A. Said explains that in Islam:

[H]uman rights ... exist only in relation to human obligations. Individuals possess certain obligations toward God, fellow humans, and nature, all of which are defined in the Shariah. When individuals meet these obligations they acquire certain rights and freedoms which are again prescribed by the Shariah. Those who do not accept these obligations have no rights, and any claims of freedom that they make upon society lack justification. ${ }^{110}$

Similarly, Donna A. Arzt states that:

The Quran has numerous references to duties (farud), but the few references to rights (huquq) are better translated as "claims" and have particular and specialized application to penal law. The only rights that are "inalienable" in the Western, natural rights sense, are those belonging to Allah and to the state, Allah's servant. ${ }^{11}$

A preference for the language of duties over rights is also evident in at least two Constitutions of states with a large Islamic population. Article 12 of the Constitution of Saudi Arabia states "The consolidation of national unity is a $d u t y$, and the state will prevent anything that may lead to disunity, sedition and

109. Sohn, supra note 104 , at 61 .

110. Arzt, supra note 4, at 205-06 (citing A. Said, Human Rights in Islamic Perspective, in HUMAN Rights: Cultural ANd IDEological Perspectives 92 (A. Pollis \& P. Schwab eds., 1980)).

111. Id. at 206 . 
separation." 112 Similarly, The Iraqi Constitution prefers the language of duties over rights in its Article 32(b): "Work is an honor and a sacred duty for every able citizen." 113

But, the mere fact that Islamic law places importance in duty does not necessarily eliminate any place in Islamic law for individual rights. Quite the contrary, Professor Sherman Jackson states that "the relative dominance and sanctity in Islamic law of individual rights gives rise to a formidable high burden of proof for alienating private rights in pursuit of broader social interests." 114 The importance of Islamic duties has been over-stated, ignoring the very real presence of private rights in Islamic law. In his authoritative treatise on Islamic law, Mohammad Hashim Kamali describes this relationship as one between haqq Allah (rights of God) and haqq al-'abd (rights of man). ${ }^{115}$ Haqq Allah, which generally embody individual duties, ${ }^{116}$ include iman (professing the faith), salah (prayers), zakah (almsgiving), the hajj (pilgramage), jihad (holy war), the 'id al-fitr (charity given at the end of Ramadan), the tithe levied on agricultural crops, the kharaj (tax on land in the conquered territories), and the hudud (penalties for theft and adultery). ${ }^{117}$ Haqq al-'abd, "which exclusively consist of the rights of men," 118 include:

The right to enforce a contract, or the right to compensation for loss, the purchaser's right to own the object he has purchased, the vendor's right to own the price paid to him, the right of pre-emption (shuf'), and so on. To enforce such rights is entirely at the option of the individual concerned; he may demand them or waive them, even without any consideration. ${ }^{119}$

This divide between haqq al-'abd and haqq Allah, not always well delineated, ${ }^{120}$ is clear evidence of the simultaneous presence of both individual

112. SAUDI ARABIA CONST. art. XII (emphasis added).

113. IRAQ CONST. art. XXXII, para. b.

114. Jackson, supra note 54 , at 410 (emphasis added).

115. KAMALI, supra note 50, at 348-50.

116. Kamali appears to consider hagq Allah as group rights rather than individual duties to the group. Based on the norms he lists, I disagree with this categorization. See KamaLI, supra note 50, at 348-50; this author's comments, supra note 99.

117. KAMALI, supra note 50, at 349.

118. Id.

119. Id.

120. See id.

According to the Maliki jurist al-Qarafi, all rights in Islam partake in the Right of God in the exclusive sense that there is no right whatsoever without the haqq Allah constituting a part thereof. Thus when a person buys a house, he exercises his private 
rights and individual duties in Islamic law. Thus, similar to the synergy between individual and 'umma in Islam, a co-existence also exists between an individual's duties and rights. This combination of rights and duties is exemplified in Article 10 of the Constitution of Iraq: "[S]ocial solidarity is the first foundation for the Society. Its essence is that every citizen accomplishes his duty in full, and that the Society guarantees the citizen's rights and liberties in full." 121 As is clear from this provision, it is the combination of individual rights and duties which leads to social solidarity, rather than a complete preference for either rights or duties.

Against this coexistence of rights and duties in the Islamic discourse, human rights law has, on the other hand, a historical normative grounding in rights, with hardly any focus on duties. ${ }^{122}$ Until very recently, the only "duties"

ld.

right insofar as it benefits him, but the transaction partakes in the Right of God insofar as the buyer is liable to pay the purchase price.

121. IRAQ CONST. ant. X.

122. STEINER \& ALSTON, supra note 1, at 323 (noting that a "fundamental characteristic of the UDHR and ICCPR [is] their foundation in the rhetoric and concept of rights"). See also CEDAW, supra note 33 (fifty references to rights and no references to duties); Convention on the Elimination of All forms of Racial Discrimination, Dec. 21, 1965, 660 U.N.T.S. 195 (entered into force Jan. 4, 1969) [hereinafter CERD] (fortyfive references to rights and no references to duties); Convention Against Torture and Other Cruel, Inhuman or Degrading Treatment or Punishment, Dec. 10, 1984, 1465 U.N.T.S. 113 [hereinafter Convention Against Torture] (entered into force June 26, 1987) (fifteen references to rights and only one reference to duties (art. 10)); Convention on the Rights of the Child, Nov. 20, 1989, 1577 U.N.T.S. 3 [hereinafter CRC] (entered into force Sept. 2, 1990) (seventy-six references to rights and three references to duties (arts. 3, 5, 14)); but see Ben Saul, In the Shadow of Human Rights: Human Duties, Obligations, and Responsibilities, 32 CoLUm. Hum. RTS. L. REV. 565, 581 (2001) (arguing that "contrary to the assertions of the human responsibilities movement, there is rich and detailed critical literature addressing ideas of human duty, obligation, and responsibility in Western rights discourse and theories of morality"). Saul's strongest argument, that "[d]uty is central to contract, tort, equity, and criminal law," is weakened by the fact that, although potentially representative of many Western domestic systems, it says little about intemational human rights' notion of duty. Id. at 583 . The closest domestic relative of international human rights law, after all, is constitutional law, which is not included on Saul's list. Similarly, Saul's argument that "Rousseau's social contract presupposed reciprocal rights and responsibilities," says little about international human rights law, which is a creature apart from Rousseau. Id. at 584. Saul's main example is "correlative duties, referring to those duties that complement specific rights." Id. at 585. But, reliance on correlative duties to make the case for the existence of duties in the Western conception of human rights is weak, since correlative duties are not duties in their own right, but mere reformulations of existing rights. See STEINER \& ALSTON, supra note 1, at 342, 361-62, 585; author's comments, infra note 125 Saul's discussion of duties language in regional human rights mechanisms seems to directly contradict his point that duties language is present in the Western rights discourse, since Saul himself claims that such regional treaties provide a mechanism for regional preferences to be acknowledged despite differing Western-dominated international preferences. Saul, supra note 122, at 591-96. When Saul does discuss international human rights, he rests his argument generally on articles of the UDHR. Id. at 58891. The UDHR is not a treaty constituting binding human rights law, and the extent to which the UDHR represents customary international law is much more complicated than Saul admits. See, e.g., Hurst Hannum, The Status and Future of the Customary International Law of Human Rights: The Status of the Universal 
language to emerge with regularity from the human rights movement was that of correlative duties, which exist only because of the presence of rights (such as the right to free speech implying a duty not to interfere in others' speech, ${ }^{123}$ or the right to be free from torture implicating a duty upon the state not to torture ${ }^{124}$ ), and are thus analytically distinct from the discourse on duties to a larger social group discussed supra in the Islamic context. ${ }^{125}$ Aside from the rare preambular reference to duties in two human rights instruments, ${ }^{126}$ human rights law has been completely grounded in the normative language of rights. ${ }^{127}$ As the name "human rights" itself suggests, "rights" and not "duties" have historically been its focus.

Against this historical focus in individual rights, there has been in the past few years a growing emphasis being placed on individual duties to groups. Beginning with the United Nations Commission on Global Governance's 1995 report on individual responsibilities, entitled Our Global Neighbourhood, ${ }^{128}$ many declarations have been produced by various international bodies, including the Universal Declaration of Human Responsibilities, produced by the Inter-

Declaration of Human Rights in National and International Law, 25 GA. J. INT'L \& COMP. L. 287 (1996). Saul does make the point, however, that both the ICCPR and ICESCR contain a reference to individual duties in their preambular paragraphs. Saul, supra note 122, at 589. Rather than establish a definitive place for duties in international human rights law, the presence of duties language merely in the preambular paragraphs of these 1960s documents, followed by the revolution of declarations based completely on duties in the 1990s, supports the point I will make in this section, that duties language in the human rights discourse is increasing, and gradually taking on a complementary place next to rights as it already maintains in Islamic law. See this author's comments, infra notes 128-142.

123. Saul, supra note 122, at 585 .

124. STEINER \& ALSTON, supra note 1, at 342.

125. Id. (emphasizing that the kinds of duties found in non-Westem contexts "are not the same as duties within a scheme of rights that are correlative to the described rights") (emphasis in original).

126. Saul, supra note 122 at 589 . The $U D H R$ art. 29 also contains a reference to duties, stating "Everyone has duties to the community in which alone the free and full development of his personality is possible." $U D H R$, supra note 14 , at art. XXIX para. 1, at 8 . When the $U D H R$ was codified in two binding Covenants, this reference to duties is now found only in the preambles.

127. See STEINER \& ALSTON, supra note 1, at 323; CEDAW, supra note 33; CERD, supra note 122; Convention Against Torture, supra note 4; CRC, supra note 122; Saul, supra note 122, at 581; STEINER \& ALSTON, supra note 1 at 342, 361-62, 585; Hannum, supra note 122.

128. Saul, supra note 122, at 573 (referring to Our Global Neighborhood: The Report of the Commission on Global Governance, http://www.sovereignty.net/p/gov/gganalysis.htm (last visited Oct. 10, 2003)). Saul also mentions several documents from international religious organizations as being central to the beginning of the international responsibilities movement, including the Parliament of the World's Religions' Declaration Toward a Global Ethic, Council for the Parliament of the World's Religions, About CPWR, 1993, http://www.cpwr.org (last visited May 15, 2001); and the report of the Inter-Action Council, In Search of Global Ethical Standards, Inter-Action Council (1996), http://www.interactioncouncil.org/ meetings/report/m961.pdf (last visited Oct. 10, 2003). 
Action Council in $1997 ; ;^{129}$ a Universal Declaration of Human Responsibilities, produced by UNESCO in $1997, ;^{130}$ a Declaration of Human Duties and Responsibilities, produced by the City of Valencia and UNESCO in $1998 ;{ }^{131}$ a Declaration of Human Duties: A Code of Ethics of Shared Responsibilities, produced by the International Council of Human Duties in 1997; ${ }^{132}$ and a Declaration of Human Responsibilities, produced by the United People's Assembly in 1998; ${ }^{133}$ and a Universal Declaration of Human Responsibilities, produced by the Hart Center in 1998. ${ }^{134}$

Perhaps most notably of all, the debate over individual duties entered the UN human rights machinery with the Resolution on Human Rights and Human Responsibilities, by the United Nations Human Rights Commission. ${ }^{135}$ This has been followed by the appointment of a Special Rapporteur to study the question of human responsibilities and duties, ${ }^{136}$ who released a preliminary report on the subject in $2002,{ }^{137}$ and will release his full report at the 59th Session of the Human Rights Commission later this year. ${ }^{138}$

In addition to this express advocacy and study of human duties, a number of other examples can be cited which implicitly do the very same thing. First, the growing movement in corporate social responsibility is easily characterized

129. Saul, supra note 122, at 574 (citing A Universal Declaration of Human Responsibilities, InterAction Council (1997), http://www.interactioncouncil.org/meetings/report/m972.doc (last visited Oct. 10, 2003)).

130. Id. (citing Universal Declaration of Human Responsibilities, UNESCO (1997), http://astro.temple.edu/ dialogue/Antho/unesco.htm (last visited Oct. 5, 2003)).

131. Id. (citing Declaration of Responsibilities and Human Duties, City of Valencia (Valencia Third Millennium Foundation) \& UNESCO (1998), http://globalization.icaap.org/content/v2.2/declare.html (last visited Oct. 2, 2003)).

132. Id. (citing The Carta of Human Duties: A Code of Ethics of Shared Responsibilities, International Council of Human Duties (1997), http://www.units.iv ichd/ (last visited Oct. 9, 2003)).

133. Id. (citing A Declaration of Human Responsibilities, United People's Assembly (1998), http://acgc.org/Documents\%20Page.htm (last visited Oct. 10, 2003)).

134. Saul, supra note 122, at 574 (citing Universal Declaration of Human Responsibilities, The Hart Center (UK) (1998)).

135. Human Rights and Human Responsibilities, U.N. Commission on Human Rights., 56th Sess., U.N. Doc. E/CN.4/RES/2000/63 (2000).

136. Decision 2001/285, U.N. Economic and Social Council, at 139, U.N. Doc. E/2001/INF/2/Add. $2(2001)$.

137. Human Rights and Human Responsibilities, Report of Mr. Miguel Alfonso Martinez, Special Rapportuer Appointed by the Sub-Commission on the Promotion and Protection of Human Rights to undertake the Study Requested by the Commission in its Rresolution 2000/63, UN Doc. E/CN.4/2002/107 (2002), http://www.unhchr.ch/Huridocda/Huridoca.nsf/e06a5300f 90 fa0238025668700518ca4/ e413d84b25dd7ac7c1256b9e003765c9/\$FILE/G0211472.pdf (last visited Oct. 9, 2003) [hereinafter Preliminary Report of the Special Rapporteur].

138. Id. para. 119. 
as a movement advocating increased individual duty, since corporations are legal individuals. ${ }^{139}$ Second, the building emphasis on the duty to protect the environment provides another salient example. Whereas many international treaties present a clean environment as a right, a growing number of such treaties are now emphasizing the duty to protect the environment over the right to enjoy it. ${ }^{140}$ Third, Saul notes that "human rights law occasionally recognizes the collective responsibility of present communities for past action by communal ancestors." 141

From a reverse moderate relativist perspective, this move from a wholly rights-centered discourse to one which combines rights with duties is another example of the international model moving closer to the Islamic one. The report of the UN Special Rapporteur studying responsibilities and duties emphasizes this point, noting that "the relationship between the individual's rights and duties" had already been "made clear in several provisions of the Cairo Declaration" on Human Rights in Islam. ${ }^{142}$ The emerging standard among human rights commentators recognizing the co-existence of rights and duties should be seen for what it is: a standard in which the Islamic conception was the benchmark for the human rights dialogue to approach.

\section{Islamic Gradualism and Dynamic Human Rights Norms}

Leila P. Sayeh and Adriaen M. Morse, Jr. use the term gradualism to describe the way Islamic law "proceeds by degrees, over time, advancing slowly but regularly" to suit evolving standards in the Islamic community itself. ${ }^{143}$ As a conceptual framework, ${ }^{144}$ gradualism can be observed in the measured and

139. Saul, supra note 122, at 597 .

140. Id. at 599 ("The right to a quality environment carries with it a 'solemn' individual 'responsibility to protect and improve the environment for present and future generations."' (citing Stockholm Declaration of the United Nations Conference on the Human Environment, http://www.mint.gov.my/policy/treaty_multidim/unche72_stockholm.htm (last visited Oct. 5, 2003). Saul mentions another treaty that he says, like the Stockholm Declaration, emphasizes duty. He explains that the Declaration of the Hague imposes "a narrower duty only on 'the community of nations' to preserve the environment for "present and future generations." Id. (citing The Hague Declaration, 1989, http://www.earthaction.org/en/archive/97-05-envins//haguedecl.html (last visited Oct. 10, 2003)).

141. Saul, supra note 122, at 599-600 (noting "compensation to Holocaust and World War II victims, victims of medical experimentation, for slavery and colonization, and for the dispossession of indigenous peoples, including genocidal child removal policies") (citations omitted).

142. Preliminary Report of the Special Rapporteur, supra note 137, 182 (citing the Cairo Declaration on Human Rights in Islam, Nineteenth Islamic Conference of Foreign Ministers, UN Doc: ST/HR/1/Rev.5 (Vol. II) (Aug. 5, 1990) (hereinafter "Cairo Declaration")).

143. Sayeh \& Morse, supra note 4, at 318.

144. In addition to describing gradualism as a conceptual framework, Sayeh \& Morse also describe gradualism as a method of interpretation. This conception of gradualism, championed by the exiled Sudanese 
time-sensitive way in which certain points of Islamic law were revealed to the Prophet. For example, beginning in a time when "Arabs had been accustomed to drink alcohol and gamble," God gradually revealed Qur'anic verses on the interdiction of drinking and gambling to the Prophet Mohammed, first revealing a mere recommendation on their disuse, then a moratorium on drinking during the hour of prayer, and finally an "outright and absolute interdiction of all intoxicants and gambling in all circumstances." 145 Sayeh and Morse argue that gradualism produced more effective, lasting social change in "[c]ertain cultural practices and habits common in Arab society [which] ... were less amenable to instant change" by preparing them "little by little" for the "full Word of God."146

scholar Abdullahi Al-An-Na'im, is open to critique. See this author, supra part III(C), at 10. An example of this gradualism in interpretation is found in the Qur'anic verses on polygamy. Potentially because of thenexisting situations (the battle of Uhud, killing ten percent of Muslim men and leaving many women and children without means of support), the Qur'anic verse 4:3 was revealed, allowing a Muslim man to marry up to 4 wives. Sayeh \& Morse, supra note 4, at 328 (citing Holy Qur'an IV:3). But, verse 4:129 later qualifies verse 4:3 by stating that "Ye are never able To be fair and just As between women, Even if it is Your ardent desire." Sayeh \& Morse, supra note 4, at 328 (citing Holy Qur'an 4:129). Under gradualism of interpretation, the two verses must be read together, the latter being accepted as a qualification of the former based on changing times. This approach has indeed been adopted by the Tunisian personal Statute Code, exemplifying the "application of principles of religious interpretation to allow Islam to best serve the needs of a modern society." Sayeh \& Morse, supra note 4, at 330 . For a thorough treatment of the interplay of these two Qur'anic verses on polygamy, see QUAMARUdDIN KAHN, STATUS OF WOMEN IN ISLAM 21-22 (1988); JOHN L. ESPOSTTO, ISLAM: THE STRAIGHT PATH 97 (1991); Sayeh \& Morse, supra note 4, at 329, n. 122 (citing Azizah F. al-Hibri, A study of Islamic Herstory: Or How Did We Ever Get into This Mess? 5 WOMEN's STUD. INT'L.F. 207, 216 (1982)). For an exhaustive account of human rights in Tunisia, which has taken gradualism to the extreme and takes international human rights norms far more seriously than some Western countries, most notably the United States. See Republique Tunisienne, Les Droits De L'Homme en Tunisie: Rapport National 1991-1993 (1993). The report describes several national mechanisms to protect international human rights, including Le Conseiller Spécial auprès du Président de la République, chargé des droits de l'homme, and Le Comité Supérieur des droits de l'Homme et des Libertés Fondamentales; several area-specific councils; relations with all relevant UN and regional mechanisms; and voluminous documentation of relations with no less than 23 non-governmental organizations. Furthermore, contrary to the United States, which prefers to speak of human rights in United States Constitutional terms, the report contains 271 pages describing rights in Tunisia framed in and using language from international human rights mechanisms. Id. at 229-500. With Tunisia as a case-study, one would be hard pressed to argue that human rights offend Islam (at least Tunisia's Islam). For a specific and exhaustive treatment of women's human rights in Tunisia, see EMMA CHITIOUI AOUU, LA TUNISIE ET LES DROITS DE L'HOMME (1992).

145. Sayeh \& Morse, supra note 4, at 320 (citing Holy Qur'an 2:219 ("They ask thee, concerning wine and gambling. Say: 'In them is great sin, And some profit, for men; But the sin is greater Than the profit."); Holy Qur'an 4:43 ("O ye who believe! Approach not prayers With a mind befogged, Until ye can understand All that ye say, Nor in a state Of ceremonial impurity"); id. at 5:90-92 ("O ye who believe! Intoxicants and gambling. (Dedication of) stones, And (divination by) arrows, are an abomination, Of Satan's handiwork; Eschew such (abomination), That ye may prosper").

146. Sayeh \& Morse, supra note 4 , at 320 . 
Through a process of slow but regular change, gradualism's various legal mechanisms adapt Islamic law to the changing needs and values in Islamic society. Sayeh and Morse note that:

\begin{abstract}
Gradualism is ideally suited to Islam because, while the Qur'an does enumerate certain legal standards, it consists primarily of very broad and general moral directives. The idea of gradualism complements the notion that Islam is a further step along the path to a greater understanding of God. Just as Muslims see Judaism and Christianity as precursors of the advent of Islam, so are the limitations and changes made upon society by the Qur'an signs of how God wishes His community to continue to evolve and grow in the future. ${ }^{147}$
\end{abstract}

Just like Islamic law under the Qur'an, human rights law is often framed in broad, generalist terms. Moreover, human rights law has never been stagnant or uncontroversial and has had to adapt to changing social standards. ${ }^{148}$ Moreover, more controversial human rights, such as ESC rights, are the most accepting of gradual change. For example, rather than adopting a rigid standard, the ICESCR requires that States parties "take steps, ... with a view to achieving progressively the full realization of the rights recognized in the present Covenant."149 Thus, just as under gradualism the Prophet Mohammed gradually prepares Muslims for the "full Word of God" in areas they are "less amenable to instant change," 150 the ICESCR's progressive realization standard is an open acknowledgment that ESC rights will also require gradual change to meet the full obligations of that Covenant in areas where they are less amenable to change due to economic or social barriers. From a reverse moderate relativist

\title{
147. Id. at 318.
}

148. The controversial, and adaptable, nature of human rights has been evident since the birth of the modern human rights movement fifty years ago, when disagreement among States made it impossible to create a binding human rights instrument containing both Civil and Political rights and Economic, Social, and Cultural Rights, leading to the adoption of two separate human rights instruments. See Comment on Historical Origins of Economic and Social Rights, in INTERNATIONAL HUMAN RIGHTS IN CONTEXT: LAW, POLITICS, MORALS 242, 244-45 (Henry J. Steiner \& Philip Alston eds., 2000); BEDERMAN, supra note 102, at 96-97 (explaining that "although the original conception was to have a single instrument on human rights, this proved politically impossible" because of ideological differences between socialist and capitalist nations). Similarly, the body of human rights law has gradually, and controversially, expanded with changing social realities, from "first generation" to "second generation" and now "third generation" rights. See id. at 95-96; Sohn, supra note 104, at 48-62; author's comments, supra notes 102-07.

149. ICESCR, supra note 76, at art. II, para. 1, at 5 (emphasis added). Compare the rigid standard in the equivalent provision of the ICCPR: "Each State Party to the present Covenant undertakes to respect and to ensure to all individuals within its territory and subject to its jurisdiction the rights recognized in the present Covenant." ICCPR, supra note 14, at art. II, para. 1., at 173.

150. Sayeh \& Morse, supra note 4 , at 320. 
perspective, the ICESCR's progressive realization standard is employing a technique as old as the Qur'an itself. ${ }^{151}$

\section{The Superiority of Reverse Moderate Relativism}

Reverse moderate relativism shares some characteristics with both strict cultural relativism and moderate cultural relativism, in that both theories place emphasis on the determination of rights by local cultures. ${ }^{152}$ But, whereas strict cultural relativism takes this criteria and creates an impasse for the advancement of universality by assuming Western norms to be inflexible, and moderate cultural relativism attempts to universalize norms only by changing the local norms, reverse moderate relativism calls for a reorganization of the examination of universal rights away from Western-oppressor starting points and towards local starting points. Schooley notes that "[c]ultural relativism's strength is its strong consideration of context. Yet, ... its weakness is 'its assumption that the importance of context proves it is not possible for one context to be superior to another in some transcendent sense." 153 Reverse moderate relativism takes cultural relativism's strength (thoughtful consideration of context), and then doubly transcends its weakness by proposing not only that one context can be superior to another, but that the superior context could and may often be the non-Western context.

\section{CONCLUSION}

As I explored in Part II, commentators on Islamic Law and human rights alike all agree that a tension between the two doctrines exists in a number of areas; but, what to do with this tension is still an open question. The three most popular theories-universalism, strict cultural relativism, and moderate cultural relativism-are each conceptually flawed. Universalism is untenable, because it eliminates the tensions simply by ignoring them. Strict cultural relativism is unsatisfactory, because discredits the whole field of human rights, which may not be necessary. An-Na'im's moderate cultural relativism, which first appears the most attractive, is perhaps the most dangerous of all: In attempting to create and expand a list of core shared rights, moderate cultural relativism treats the international norm as the neutral benchmark to be achieved, with dangerous neo-colonialist implications. In Part IV, I proposed a new theory, reverse moderate relativism, which accepts the virtues of moderate cultural relativism

151. Id. at 318 (noting that western Common Law also adopts a gradualist approach, although mistakenly framing that argument from a moderate cultural relativist perspective that gradualism "parallels the common law study in analogy and reason").

152. See Tesón, supra note 35 , at 678 .

153. Schooley, supra note 20 , at 682 . 
while avoiding the western-centric detrimental focus on international norms as neutral benchmark standards to be achieved which is the hallmark of moderate cultural relativism. By refocusing attention to areas where international norms are approaching Islamic ones, reverse moderate relativism offers a superior outlook on relativism which avoids the neo-colonial and western-centric undertones of moderate cultural relativism.

It must be emphasized that reverse moderate relativism does not claim any causative link between (often) longstanding Islamic traditions and developing human rights norms. Perhaps the theory is open to criticism as nothing more than a catalogue of coincidences. But, such a critique ignores the profound importance of restructuring the universality debate from Western neutrals to local neutrals. Although reverse moderate relativism cannot claim to be causative (Indeed, why would it want to? Causation only lurks behind moderate cultural relativism as a neo-colonial phantom.), and this preliminary inquiry certainly cannot claim to be exhaustive, it provides a necessary change in momentum, a change of focus and perspective. The universality story has been told and rejected. An-Na'im's moderate cultural relativist theory, although a step in the right direction, lives in the shadow of a neo-colonialist cloud. Perhaps, with the refreshing new focus on rights universalization by Western gravitation towards certain local cultures, the stalled universality debate can be given some true meaning. 